\title{
The Coal-Fired Power Plant Based on Minimizing the Total Cost Inventory System Optimization Research
}

\author{
Jianna Zhao \\ Department of Economics and Management \\ North China Electric Power University, China \\ No.689 Huadian Road, Beishi district, Baoding, 071003, \\ China \\ zhjnzhf@163.com
}

\author{
Wenduo Dong \\ Department of Economics and Management \\ North China Electric Power University, China \\ No.689 Huadian Road, Beishi district, Baoding, 071003, \\ China \\ dongwenduo2011@163.com
}

\begin{abstract}
In terms of the power plant supplies warehouse management, warehouse management ownership still exist unclear, management does not reach the designated position, inventory optimization has obvious flaw. Therefore solve the above problem, this paper supplies rational order and inventory optimization of inventory system to establish a stable and efficient power plant, through the establishment of materials to rationalize order model and the optimization model in order to ensure stock material flow unimpeded. In turn, reduce the inventory cost for thermal power enterprises; strengthen control of the inventory level. This article break only to the original material classification model, this paper, in addition to the classification of materials also joined the operation model, and then joined the inventory rebuilding and operational model, make the minimum cost of the inventory system has more research value.
\end{abstract}

Keywords-material classification; regional warehouse; turnover warehouse

\section{INTRODUCTION}

Inventory problem of research to the enterprise management has important guiding role, especially in power plant inventory control problem of minimizing the cost compared with the traditional inventory control problems are quite different, more has a guiding significance for coal-fired power plants. So on the classification of the power plant supplies the reasonable order quantities and materials can effectively optimize the inventory model. According to optimize good power plant inventory model, used in some thermal power enterprise, from practice to reduce the inventory cost of thermal power plants.

\section{POWER SUPPLIES, CLASSIFICATION AND DETERMINATION OF MATERIAL ORDER MODEL}

\section{A. Primary and secondary factors classification}

Primary and secondary factors classification can be referred to as pareto analysis, mainly by pareto set. Primary and secondary factors classification and is called the $\mathrm{ABC}$ classification, the main process is by setting priorities, grasp the main characteristics of the corresponding things, then go to line up, under these conditions can effectively targeted control inventory. Depending on the degree of important materials in the inventory management, it can be divided into class A, class $\mathrm{B}$ and class $\mathrm{c}$ is not important, important commonly according to its characteristics to take the corresponding control methods. Is important to control for A class of materials, mainly small amounts of high value, the key material. Class B main characteristic is similar to the amount and variety, need only routine controls. Class $\mathrm{C}$ main characteristic is numerous, but the corresponding value is not high, belongs to has a large inventory of cheap materials, so from the inventory cost, this kind of material to take inventory as little as possible ${ }^{[1]}$. Therefore for primary and secondary factors analysis method can determine the material classification management table. The following table I.

TABLE I. MATERIAL CLASSIFICATION MANAGEMENT TABLE

\begin{tabular}{|l|l|c|c|}
\hline \multirow{2}{*}{ project } & \multicolumn{3}{c|}{ Material classification management table } \\
\cline { 2 - 4 } & Class $\boldsymbol{A}$ & Class $\boldsymbol{B}$ & Class $\boldsymbol{C}$ \\
\hline $\begin{array}{l}\text { The degree of } \\
\text { control }\end{array}$ & strict control & $\begin{array}{c}\text { Intermediate } \\
\text { control }\end{array}$ & primary control \\
\hline $\begin{array}{l}\text { Inventory } \\
\text { calculation }\end{array}$ & $\begin{array}{l}\text { Detailed } \\
\text { calculation }\end{array}$ & $\begin{array}{c}\text { Intermediate } \\
\text { calculation }\end{array}$ & $\begin{array}{c}\text { Simple } \\
\text { calculation }\end{array}$ \\
\hline $\begin{array}{l}\text { In and out of the } \\
\text { record }\end{array}$ & $\begin{array}{l}\text { detailed } \\
\text { record }\end{array}$ & $\begin{array}{c}\text { Intermediate } \\
\text { records }\end{array}$ & Simple record \\
\hline $\begin{array}{l}\text { Inventory check } \\
\text { frequency }\end{array}$ & frequent & intermediate & lower \\
\hline Safety stock & small & intermediate & big \\
\hline
\end{tabular}

\section{B. The key factor analysis method}

Key factor analysis method is introduced to analyze key factors in the inventory management, the inventory according to the classification of key, and manage method, respectively ${ }^{[2]}$ CVA classification than ABC inventory classification management has a greater purpose. In use, people tend to think of inventory to make high priority, to show the importance of this kind of goods, as a result, the high-priority inventory is too much, in the end, what kind of inventory did not get the attention they deserve, even make the inventory management the lack of primary and secondary. The use of CVA classification of inventory management, to customers in the 
enterprise must establish on the basis of a detailed classification management. On the basis of the classification of CVA supplies are obtained. The following table II.

TABLE II. CVA CLASSIFICATION OF GOODS

\begin{tabular}{|c|c|c|}
\hline \multicolumn{3}{|c|}{ CVA classification of goods } \\
\hline $\begin{array}{c}\text { Inventory } \\
\text { type }\end{array}$ & characteristics & Management measures \\
\hline $\begin{array}{l}\text { most } \\
\text { priority }\end{array}$ & $\begin{array}{l}\text { Key materials and class A } \\
\text { key customer's inventory }\end{array}$ & Not allowed out of stock \\
\hline $\begin{array}{l}\text { Higher } \\
\text { priority }\end{array}$ & $\begin{array}{l}\text { Basic materials and class B } \\
\text { stock of customer }\end{array}$ & $\begin{array}{l}\text { Occasionally allowed } \\
\text { out of stock }\end{array}$ \\
\hline $\begin{array}{l}\text { Medium } \\
\text { priority }\end{array}$ & $\begin{array}{l}\text { the more important materials } \\
\text { and class C customer } \\
\text { inventory }\end{array}$ & $\begin{array}{l}\text { Allowed within a } \\
\text { reasonable range out of } \\
\text { stock }\end{array}$ \\
\hline $\begin{array}{l}\text { lower } \\
\text { priority }\end{array}$ & $\begin{array}{l}\text { The need of the goods but } \\
\text { can replace the goods }\end{array}$ & Allowed out of stock \\
\hline
\end{tabular}

\section{Material order model is established in this paper}

1) for A class is not allowed out of stock, the order of time $T$, the total order $Q$, order and the total cost $C$ is respectively:

$T=\sqrt{\frac{2 C_{1}}{C_{0} W}} \quad Q=W T=\sqrt{\frac{2 C_{1} W}{C_{3}}} \quad C=\frac{C_{1}}{T}+\frac{1}{2} C_{0} W T=\sqrt{2 C_{0} C_{1} W}$

The $\mathrm{C}_{0}$ storage fee for each year for every unit of goods, $\mathrm{C}_{1}$ factory required assemble fee for each cycle, frequency $\mathrm{W}$ for material demand.

2) for a class B allows the shortage of goods, the order of time $T$, the total order $Q$, order and the total cost $C$ is respectively:

$T=\sqrt{\frac{2 C_{1}\left(C_{0}+C_{3}\right)}{C_{0} W C_{3}}} \quad Q=\sqrt{\frac{2 W G_{1}}{C_{0}} * \frac{C_{0}+C_{3}}{C_{3}}} \quad C=\sqrt{\frac{2 C_{0} C_{3} C_{1} W}{C_{0}+C_{3}}}$

Including $\mathrm{C}_{0}$ storage fee for each year for every unit of goods, $\mathrm{C}_{1}$ factory the subscription fee for each cycle, $\mathrm{C}_{3}$ is out of stock cost, W frequency for material demand.

3) for $C$ class allows materials in a reasonable range, the order of time $T$, the total order $Q$, order and the total cost $C$ is respectively:

$T=\sqrt{\frac{2 C_{1}}{C_{0} W}} * \sqrt{\frac{C_{0}+C_{3}}{C_{3}}} * \sqrt{\frac{H}{H-W}} \quad Q=W T=\sqrt{\frac{2 C_{2} W}{C_{0}}} * \sqrt{\frac{C_{0}+C_{3}}{C_{3}}} * \sqrt{\frac{H}{H-W}}$

$C=\sqrt{2 C_{0} C_{1} W} * \sqrt{\frac{C_{0}}{C_{0}+C_{3}}} * \sqrt{\frac{H-W}{H}}$

Of $\mathrm{C}_{0}$ storage fee for each year for every unit of goods, $\mathrm{C}_{1}$ factory the subscription fee for each cycle, $\mathrm{C}_{3}$ is out of stock cost, frequency $\mathrm{W}$ as supplies demand, $\mathrm{H}$ as aggregate demand.

\section{BASED ON THE THERMAL POWER PLANTS UNDER THE} MATERIAL CLASSIFICATION INVENTORY SYSTEM OPTIMIZATION

Because the virtual warehouse belongs to the command of planning, stock is less, mainly aimed at the first regional library and turnover of two level optimization. Regional library and optimization is the basic way of layout, according to the qualitative analysis from the warehouse selected alternative regional libraries. Set of libraries and the optimization is the basic way of, based on the scope of the regional library covered other existing warehouse will be used as alternative of library ${ }^{[3]}$.
Then through modeling, choose suitable warehouse from alternative library. Regional library should ultimately meet in determining content distribution distance constraints, can cover existing libraries full range of distribution of the region in the province, the number of regional library is minimal. While the number of turnover of library should be under the condition of satisfy the distribution distance constraints, sure to cover all existing turnover library distribution range of minimum quantity.

Regional warehouse, the turnover warehouse renovation on the selected mainly refers to the cost of reconstruction cost of the warehouse, due to calculate storage per square meter, through regional warehouse, the turnover warehouse renovation costs should keep inventories to calculate the area of the storehouse, the turnover warehouse renovation costs need rebuilding costs ${ }^{[4]}$.

\section{A. regional warehouse renovation costs}

Regional warehouse storage area:

$\frac{R s}{\theta V}$

Regional warehouse renovation:

$B_{1} M_{s 1}+B_{2} M_{s 2}+B_{3} \beta s\left(\frac{R s}{\theta V}-M_{s 1}-M_{s}\right)$

$M s \geq \frac{R s}{\theta V}$

$\beta s\left\{\begin{array}{cc}0 & M s 1+M s 2 \geq \frac{R s}{\theta V} \\ 1 & M s 1+M s 2<\frac{R s}{\theta V}\end{array}\right.$

Regional warehouse fixed construction fee $\mathrm{O}$

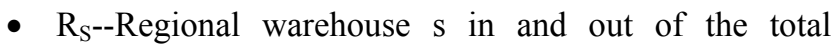
amount of goods each year;

- $\theta$--Inventory turnover ratio;

- V-- regional average per square meter, the turnover warehouse inventory amount;

- $\mathrm{B}_{1^{--}}$indoor storage modification cost one by one;

- $\mathrm{B}_{2--}$ outdoor storage modification cost one by one;

- $\mathrm{B}_{3^{--}}$to indoor and outdoor storage new average cost;

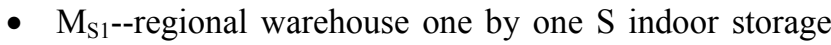
area;

- $\mathrm{M}_{\mathrm{S} 2}$--regional warehouse one by one "S outdoor storage area;

- $\mathrm{M}_{\mathrm{S}^{--}}$regional warehouse one by one "S total area;

- $\beta_{\mathrm{S}^{--}}$regional warehouse $\mathrm{S}$ whether need new index 0-1;

- Os-- Regional warehouse $m$ construction fixed costs.

- Regional warehouse total cost of reconstruction: 
$\sum_{s=1}^{S} \Phi\left(B M_{1}+B_{2} M_{2}+B 3 \beta\left(\frac{R s}{\theta V}-M_{1}-M_{2}\right)+O_{s}\right)$

$\Phi$ s is Whether construction parameter 0-1.

\section{B. The turnover warehouse renovation costs}

Turnover warehouse storage area:

$\frac{R}{Q}$

Turnover warehouse renovation:

$B_{1} M_{t 1}+B_{2} M_{t 2}+B_{3} \beta_{t}\left(\frac{R_{t}}{\theta V}-M_{t 1}-M_{t 2}\right)$

$M \geq \frac{R}{Q V}$

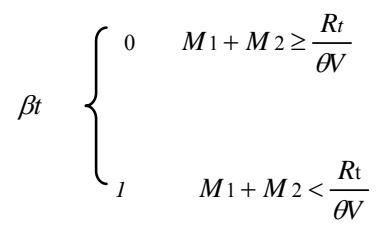

- $\mathrm{R}_{\mathrm{s}}$--turnover warehouse $\mathrm{t}$ one by one in and out of the total amount of goods each year:

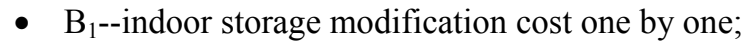

- $\mathrm{B}_{2}$--outdoor storage modification cost one by one;

- $\mathrm{B}_{3}$--to indoor and outdoor storage new average cost;

- $\mathrm{M}_{\mathrm{t} 1}$--turnover storehouse indoor storage area;

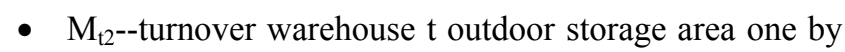
one;

- Mt-- turnover warehouse t area;

- $\quad \beta_{\mathrm{t}}$--Whether the turnover warehouse $\mathrm{t}$ need new index $0-1$;

- $\mathrm{O}_{\mathrm{t}}$--turnover storehouse $\mathrm{t}$ construction fixed costs.

Turnover warehouse renovation:

$\sum_{\mathrm{t}=1}^{T} \Phi\left(B M_{1}+B_{2} M_{2}+B_{3} \beta\left(\frac{R}{\theta}-M_{1}-M_{2}\right)+0_{t}\right)$

\section{C. regional warehouse, warehouse operation cost}

Running costs including warehousing personnel cost and warehouse operations cost two parts:

$$
V_{\mathrm{st}}=\sum_{\mathrm{s}=1}^{\mathrm{s}} \Phi_{s}\left(k_{1}+k_{2}\right)\left[B_{1} M_{1}+B_{2} M_{\mathrm{s} 2}+B 3 \beta \beta_{s}\left(\frac{R S}{\theta V}-M_{\mathrm{s}_{1}}-M_{\mathrm{s}_{2}}\right)\right]
$$

\section{CASE STUdY}

According to the above classification of materials and the establishment of the warehouse cost model, selection of a certain power plant, to optimize its inventory systems, and storage and network will be transformed into a "regional library + turnover library" system. Integrating 20 warehouse for optimizing the number $\mathrm{n}$ of regional warehouses, each warehouse will be responsible for more than its surrounding distribution task of library. From relying on experience in procurement, based on classification for effective purchase and change ${ }^{[5]}$. And the procurement of goods according to the regional warehouse and turnover warehouse model optimization $^{[6]}$.

According to the classification of the power plant supplies and use(1),(2),(3)models can be calculated from the following form. The following table III.

TABLE III. CLASSIFICATION OF PURCHASE TABLES

Unit (month. Ten thousand yuan. T)

\begin{tabular}{|l|c|c|c|c|c|c|c|c|}
\hline \multicolumn{7}{|c|}{ Content } & \multicolumn{7}{|c|}{} \\
\hline & \multicolumn{7}{|c|}{ Cassification of purchase tables } \\
\hline & C0 & C1 & C3 & W & H & T & Q & C \\
\hline A & 4 & 50 & & 100 & & 0.5 & 50 & 200 \\
\hline B & 4 & 50 & 26 & 100 & & 1 & 54 & 59 \\
\hline C & 1.25 & 4 & 0.15 & 28 & 300 & 0.05 & 6 & 29.1 \\
\hline & & & & \multicolumn{7}{c|}{ Classification of purchase tables }
\end{tabular}

According to the 3-1 to 3-11 models, can be concluded that the regional warehouse and turnover warehouse model parameters in the following table IV.

TABLE IV. MODEL DATA TABLE

\begin{tabular}{|l|c|}
\hline Model parameters & default value \\
\hline velocity & 50 \\
\hline $\begin{array}{l}\text { current average warehouse inventory } \\
\text { amount per square metre }\end{array}$ & 16313 Yuan/year \\
\hline Indoor and outdoor new average cos & 7432.8 Yuan/square \\
\hline Indoor and outdoor rebuilding costs & $\begin{array}{c}11866.5 Y \text { Yuan/square,29 } \\
99.1 Y \text { Yuan/square }\end{array}$ \\
\hline $\begin{array}{l}\text { average per square meter warehousing } \\
\text { Labour cost }\end{array}$ & 2587.4 Yuan/square \\
\hline
\end{tabular}

According to according to the model (4)to (14), using Matlab to calculate, can draw at the regional library and turnover warehouse 17 or 18 can cover all the power demand, and on the basis of the data warehouse and turnover warehouse to do the following regional contrast. The following table $\mathrm{V}$ is optimization data and cost.

TABLE V. OPTIMIZATION DATA AND COST

\begin{tabular}{|l|c|c|c|}
\hline \multirow{2}{*}{} & \multicolumn{3}{|c|}{ optimization data and cost } \\
\cline { 2 - 4 } & Regional library & Turnover library & $\begin{array}{c}\text { total } \\
\text { cost/yuan }\end{array}$ \\
\hline Alternative 1 & 4 & 14 & 2356627053 \\
\hline Alternative 2 & 5 & 12 & 2286522113 \\
\hline Alternative 3 & 6 & 13 & 2100151673 \\
\hline
\end{tabular}

\section{SUMMARY}

Through examples in this chapter proves the feasibility of the power plant supplies the warehouse system optimization. 
Electrical material warehouse is a complexity of multiple fusion network, affects the electrical material flow cost, efficiency, safety, and other aspects of, so its importance is becoming more and more obvious. This article emphatically studies the coal-fired power plant based on minimizing the total cost of warehouse system optimization, and other elements to provide practical guidance for the further optimization of power plant logistics.

\section{REFERENCES}

[1] Antunes. Peeters. On solving complex multi-period location models using simulated annealing $[\mathrm{J}]$. European Journal of Operational Research.2011.130:190-201.
[2] Kennedy J, Eberhart R. Particle swarm optimization [A]. in: Proceedings of the 4th IEEE International Conference on Neural Networks [C],Piscataway: IEEE Service Center, 2015.

[3] Campana E F, Fasano G, Pinto A. Dynamic system analysis and initial particles position in particle swarm optimization [A]. in: Proc. IEEE Swarm Intell. Symp. [C], May, 2012 :02-209

[4] KhalidBichou, RiehardGray. "A logistics and supply chain management approach to port Performance measurement."'[J].Routledge, 2014, 3

[5] Nahmias,S.,Smith,S.A. Scaling down multi-echelon inventory problems[J].International Journal of Production Economics, 2011, 71:255-261

[6] Jen-ming Chen, Tsung-hui Chen. The multi-item replenishment problem in a two echelon supply chain age effect of centralization versus decentralization[J].Computers \&Operations Research,2011,32:31913207 